\title{
Bio-formulation of Halotolerant Phosphate Solubilizing Enterobacter cloacae HFZ-H4 Strain to Screen Different Carrier Materials and their Shelf Life Study
}

\author{
Mohammad Hafeez ${ }^{1}$, P. W. Ramteke ${ }^{1}$, Rubina Lawrence ${ }^{1}$, Rambharose ${ }^{2}$, \\ B.G. Suresh ${ }^{3}$, Supriya Kumari ${ }^{1}$, Ajay Kumar Singh ${ }^{1}$, Ankit Singla ${ }^{4}$, \\ Anupriya Paul ${ }^{5}$, Shalini Masih ${ }^{5}$ and Harison Masih ${ }^{1 *}$ \\ ${ }^{1}$ Department of Industrial Microbiology, Jacob Institute of Biotechnology and Bioengineering \\ (JSBB), Sam Higginbottom University of Agriculture, Technology and Sciences (SHUATS), \\ Allahabad, Uttar Pradesh-211007, India \\ ${ }^{2}$ Department of Soil and Environmental Sciences, ${ }^{3}$ Department of Genetics and \\ Plant Breeding SHUATS, India \\ ${ }^{4}$ Regional Centre of Organic Farming, Ministry of Agriculture and Farmers Welftare, Govt. of \\ India, Bhubaneswar, 751021 \\ ${ }^{5}$ Department of Mathematics and Statistics, SHUATS, India \\ *Corresponding author
}

\section{A B S T R A C T}

\section{Keywords}

Bio-formulatoin,

Halotolerant,

Enterobacter cloacae, Shelf life and Fly-ash

Article Info

Accepted:

16 December 2017

Available Online:

10 January 2018

The present research work was conducted to screen different carrier materials for halotolerant phosphate solubilizing Enterobacter cloacae HFZ-H4 strain to be used as biofertilizer formulation and study of their shelf life. Formulations of Enterobacter cloacae HFZ-H4 strain in fly-ash, saw dust and rice husk ash were screened for the better survival as bacterial bio-fertilizers formulation and result showed that Fly ash was found as best carrier material for bio-formulation and fly ash was further used as carrier material for optimization and shelf life study stored at optimized condition up to six months. Optimization of Fly ash based bio-formulation revealed that $25^{\circ} \mathrm{C}$ temperature and $30 \%$ moisture content were find as best condition for bio-fertilizer formulation to survive. Shelf life study in (fly ash) revealed that the population of bacteria gradually decreases with storage time and maximum population was observed at zero day $\left(51 \times 10^{8} \mathrm{cfu} / \mathrm{g}\right)$ of formulation. The population of Enterobacter cloacae HFZ-H4 was declined upto $06 \mathrm{log}$ at $10^{8} \mathrm{cfu} / \mathrm{g}$ after six months of storage which is within the permissible limit. From results of this study it can be concluded that the halotolerant strain of Enterobacter cloacae HFZ-H4 formulations in fly ash could be a better option for the growth and yield of the crop in sodic/saline soil.

\section{Introduction}

Phosphate solubilizing bacteria (PSB) are used as bio-fertilizer since 1950's. Different types of organic acids e.g., carboxylic acid is secreted by these microorganisms (Deubel and Merbach, 2005) thus lowering the $\mathrm{pH}$ in the rhizosphere and consequently dissociate the bound forms of phosphate like $\mathrm{Ca}_{3}\left(\mathrm{PO}_{4}\right)_{2}$ in calcareous soils. The role of phosphate 
solubilizing microorganism in their abilities to reduce the $\mathrm{pH}$ of the surroundings by the production of organic acids (Chen et al., 2006), production of acid and alkaline phosphatises (Rodríguez and fraga, 1999) and to $\mathrm{H}+$ protonation (Illmer and Schinner, 1995). These organic acids can either dissolve phosphates as a result of anion exchange or can chelate $\mathrm{Ca}, \mathrm{Fe}$ or $\mathrm{Al}$ ions associated with the phosphates (Rajankar et al., 2007, Gyaneshwar et al., 2002). It is mostly deficient in soils as it is fixed as water insoluble iron and aluminium phosphates in acidic soils or calcium phosphate in alkaline soils (Singh and Kapoor 1994).

Phosphate solubilizing microorganisms (PSM) particularly those belonging to the genera Bacillus sp. and Pseudomonas sp., and many others possess the ability to bring insoluble phosphates in soil into soluble forms by secreting organic acids such as citric acid formic, acetic, propionic, lactic, fumaric and succinic acids (Rashid et al., 2004, Ivanova et al., 2006, Rodríguez and Fraga, 2007). These organic acid increases the acidity in soil and decreases the soil $\mathrm{pH}$ that is more effective in soil aggregation processes and servable of plants and microorganisms which results in improving the soil quality as well as the physico-chemical properties of soil.

Production of organic acids results in acidification of the microbial cell and its surroundings. These bacteria can grow on various phosphorus containing medium and play an important role in supplying phosphate compound to plants in a more environmentally-friendly and sustainable manner (Khan et al., 2007).

Bio-fertilizers are usually prepared as carrierbased inoculants containing effective microorganisms. A suitable carrier material was selected after screening of a number of locally available materials to ensure maximum survival of the inoculated bacteria during storage and transportation. Incorporation of microorganisms in carrier material enables easy-handling, long-term storage and high effectiveness of bio-fertilizers. Inoculum carriers provide as media in bio-fertilizer production, controlling quality and shelf life of bacterial inoculants by serving as microenvironment for microorganisms. Other than, various types of carrier materials storage temperatures and moisture content are important factors determining shelf life of bioinoculants (Kremer and Peterson, 1983), and acceptance of agricultural products (Bashan, 1998). Fly-ash which is generally recognized as waste being generated in large quantity in thermal power stations, and causes environmental hazard, has been reported to promote crop growth in various trials conducted under National Fly-ash Mission Programs (Kumar, et al., 1999). A good carrier material have following characteristics: (1) non-toxic to inoculated bacterial strain, (2) should good moisture absorption capacity, (3) easy to process and free of lump-forming materials, (4) easy to sterilize by autoclaving or gamma-irradiation, (5) should available in large amounts, (6) chief, (7) good adhesion to seeds, and (8) good pH buffering capacity (9) should non-toxic to plant.

Storage of bio-fertilizers inoculants in a storehouse without refrigerator in the range of 5 to $30{ }^{\circ} \mathrm{C}$ usually causes reduction in microbial shelf life. A number of researchers have evaluated for suitable carrier materials from agricultural and other wastes and investigated the effect of different temperatures and different moisture content on shelf life of bio-fertilizer formulations (Thungtrakul, 1987; Rajakumar and Lakshmanan, 1995; Saleh et al., 2001).

The utilization of these carrier materials reduces to cost of the product giving additional advantage to soil or crops. 
Halotolerant Enterobacter cloacae HFZ-H4 strain isolated from sodic soil, was formulated in different carrier materials, with an aim to explore feasibility of using it as a carrier for shelf life study as commercial formulation.

\section{Materials and Methods}

The present studies were conducted in the Research Laboratory of the Department of Industrial Microbiology, Sam Higginbottom University of Agriculture, Technology and Sciences, Allahabad, Uttar Pradesh, India.

\section{Multiplication of Enterobacter cloacae HFZ-H4 strain}

Enterobacter cloacae HFZ H4 strain with accession number (MG255304) was grown on Pikovaskaya broth medium tubes. After checking the culture for purity and proper growth, the culture was transferred to conical flask containing sterilized liquid Pikovaskaya broth medium on a rotary shaker at $150 \mathrm{rpm}$ for $4-5$ days at $30{ }^{\circ} \mathrm{C}$ (Rao, 1986).

\section{Screening of carrier materials}

Fly-ash, Rice husk ash and Saw dust obtained from different sources and packed in autoclavable propylene bag and sterilized in an autoclave.

The different carriers based bio-fertilizers formulations were screened for better survival of the bio-fertilizers strains. A high count of Enterobacter cloacae HFZ-H4 to contain about $>10^{9} \mathrm{CFU}$ per ml were mixed manually in sterilized carrier of $40 \%$ water holding capacity so as to attained final moisture content of carrier to $30-35 \%$ (FCO, 2006), and packed in low density polythene bags. The final preparation contained more than $10^{8}$ cells/g of formulation (Rao, 1986).
Optimization of storage temperature $\left({ }^{\circ} \mathrm{C}\right)$ and moisture content (\%) on bioformulation

The optimization was studies under following conditions.

Storage temperature: at 20, 25, 30, 35 and 40 $\left({ }^{\circ} \mathrm{C}\right)$.

Moisture content: at 20, 25, 30, 35 and 40 (\%).

\section{Shelf life study of halotolerant bio-fertilizer formulation}

Shelf life of the bio-fertilizer formulations was studied by drawing samples at regular intervals of 20 - days up to six months from date of mixing. The colony forming unit (CFU) was estimated by "serial dilution pour plate method" using Pikovaskaya Agar medium (Cappuccino and Sherman 2004).

\section{Results and Discussion}

The results and discussion of the study are reported in succeeding page under the following headings.

\section{Screening of carrier materials}

Three low cost and indigenously available substrates, Saw dust, Rice husk ash and Fly ash (FA) were selected for evaluation of carrier materials suitable to survive biofertilizers strains. Five day old Enterobacter cloacae HFZ-H4 strain broth cultures with a population load of $>10^{9}$ cell $/ \mathrm{ml}$ were blended with these carrier materials. Quantity of the broth added, was adjusted to obtain a moisture level of $35-40 \%$ of total water holding capacity of the carriers. Prepared carrier based bio-fertilizer formulations packets were checked for viability. Viability of added bacterial cells and other microbial contaminants were monitored by serial 
dilution and standard plate count method on Pikovaskaya Agar medium plates.

The present study results showed that there were significant differences in survival of bacterial strain among carrier materials and Fly ash gave the highest cfu count (49) followed by saw dust (47) and rice husk ash (41), (Table- 1). Similar results on viability of fly-ash alone compare to lignite: soil $(1: 1)$ have been reported by (Gaind and Gaur, 2004). The results were in agreement with the findings of (Jayaraj et al., 2005; Khan et al., 2007). Many other research findings have also suggested that Fly-ash alone and in combination with other materials is an excellent carrier for bio-formulation of Rhizobium (Kumar and Gupta, 2008). Fly ash offers certain benefits when it is used as carrier material.

Table.1 Screening of different carrier materials

\begin{tabular}{|c|l|c|}
\hline S. No. & Carrier material & Cfu counts x 10 $\mathbf{8}^{\mathbf{8}} / \mathbf{g}$ \\
\hline 1. & Fly Ahs & $49 \pm 4.34 \mathrm{a}$ \\
\hline 2. & Rice husk ash & $41 \pm 1.00 \mathrm{~b}$ \\
\hline 3. & Saw dust & $47 \pm 1.73 \mathrm{a}, \mathrm{b}$ \\
\hline
\end{tabular}

Different letters in each row denote significant differences $(\mathrm{p}<0.05)$ among the treatments according to a Tukey's HSD test. Mean value \pm standard deviation $(n=3)$.

Table.2 Effect of storage temperature $\left({ }^{\circ} \mathrm{C}\right)$ on bio-formulation

\begin{tabular}{|c|c|c|}
\hline S. No. & Temperature $\left({ }^{\circ} \mathrm{C}\right)$ & Cfu counts $\times \mathbf{1 0}^{8} / \mathrm{g}$ \\
\hline 1. & 20 & $42 \pm 4.58 \mathrm{a}$ \\
\hline 2. & 25 & $43 \pm 1.73 \mathrm{a}$ \\
\hline 3. & 30 & $40 \pm 2.65 \mathrm{a}$ \\
\hline 4. & 35 & $31 \pm 2.65 \mathrm{~b}$ \\
\hline 5. & 40 & $22 \pm 3.00 \mathrm{c}$ \\
\hline
\end{tabular}

Different letters in each row denote significant differences $(\mathrm{p}<0.05)$ among the treatments according to a Tukey's HSD test. Mean value \pm standard deviation $(n=3)$.

Table.3 Effect of moisture content (\%) on bio-formulation

\begin{tabular}{|c|c|c|}
\hline S. No. & Moisture content (\%) & Cfu counts $\mathbf{x} \mathbf{1 0}^{8} / \mathrm{g}$ \\
\hline 1. & 20 & $20 \pm 1.00 \mathrm{~d}$ \\
\hline 2. & 25 & $25 \pm 0.00 \mathrm{c}$ \\
\hline 3. & 30 & $43 \pm 3.46 \mathrm{a}$ \\
\hline 4. & 35 & $37 \pm 1.52 \mathrm{~b}$ \\
\hline 5. & 40 & $37 \pm 1.00 \mathrm{~b}$ \\
\hline
\end{tabular}

Different letters in each row denote significant differences $(\mathrm{p}<0.05)$ among the treatments according to a Tukey's HSD test. Mean value \pm standard deviation $(\mathrm{n}=3)$. 
Table.4 Shelf life of E. cloacae in fly ash at optimized conditions (Cfu x $10^{8} / \mathrm{g}$ )

\begin{tabular}{|c|c|c|}
\hline S. No. & Shelf life (Day) & Cfu counts $x 10^{8} / \mathrm{g}$ \\
\hline 1. & 00 & $51 \pm 3.61 \mathrm{a}$ \\
\hline 2. & 20 & $48 \pm 4.36 \mathrm{a}$ \\
\hline 3. & 40 & $42 \pm 2.65 a, b$ \\
\hline 4. & 60 & $33 \pm 5.57 b, c$ \\
\hline 5. & 80 & $27 \pm 2.65 c, d$ \\
\hline 6. & 100 & $23 \pm 2.65 d$ \\
\hline 7. & 120 & $20 \pm 2.00 \mathrm{~d}$ \\
\hline 8. & 140 & $19 \pm 2.65 \mathrm{~d}, \mathrm{e}$ \\
\hline 9. & 160 & $10 \pm 2.65 e, f$ \\
\hline 10. & 180 & $06 \pm 1.73 f$ \\
\hline
\end{tabular}

Different letters in each row denote significant differences $(\mathrm{p}<0.05)$ among the treatments according to a Tukey's HSD test. Mean value \pm standard deviation $(n=3)$.

Fig.1 Population of Enterobacter cloacae in fly ash at optimized conditions (Cfu x $10^{8} / \mathrm{g}$ )

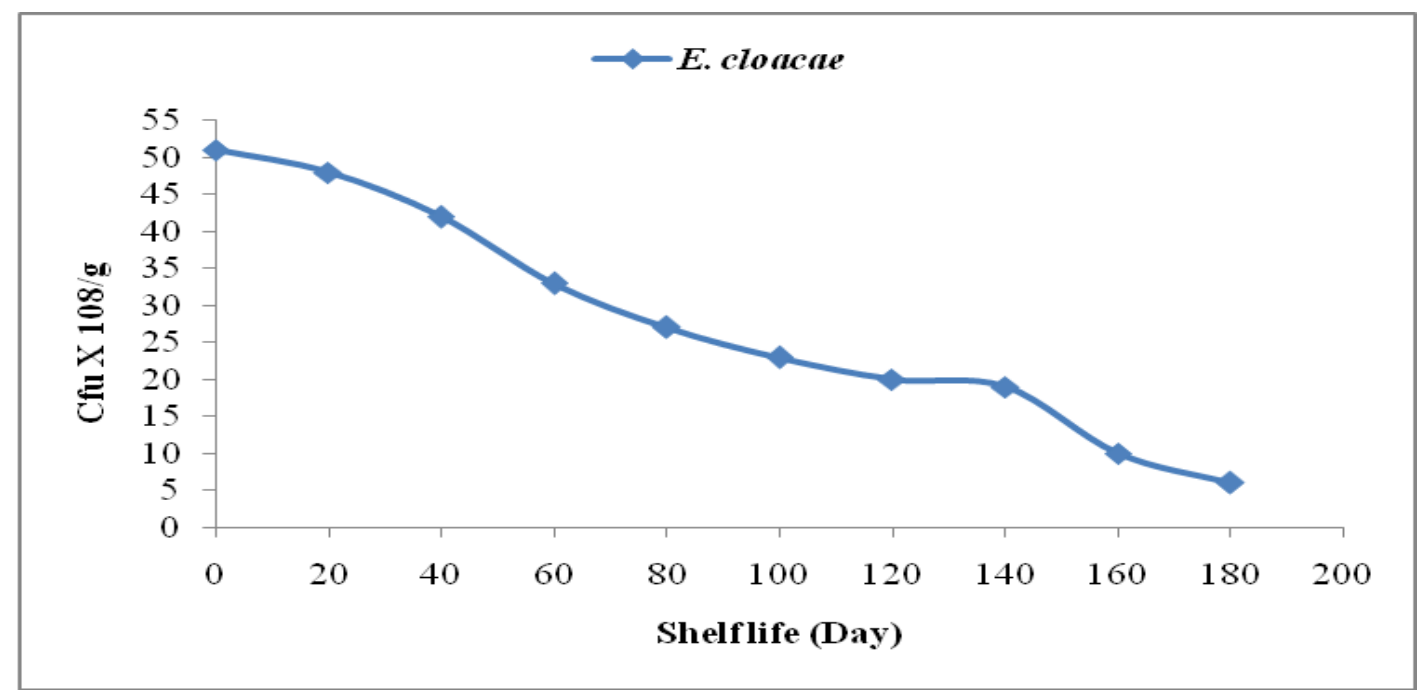

It Improves water holding capacity/porosity, Optimizes $\mathrm{pH}$ value, Works as a liming agent, Provides micro and macro nutrients like $\mathrm{Fe}$, $\mathrm{Zn}, \mathrm{Cu}, \mathrm{Mo}, \mathrm{B}, \mathrm{Mn}$ and $\mathrm{K}, \mathrm{P}, \mathrm{Ca}, \mathrm{Mg}, \mathrm{S}$ etc. (Vitekari et al., 2012). The data was analyzed statistical and showed that there were significant differences in different carrier based bio-formulations $(\mathrm{p}<0.05)$.

\section{Optimization of bio-formulation (Fly ash)}

Optimization of the bio-formulation for the best survival of the bio-fertilizer strains under different condition such as optimum moisture content and optimum storage temperature was as discussed below.

The effect of storage temperature on the cfu count was studied. The influence of storage temperature on cfu count is related to the temperature tolerant of the bacterial strain. The storage temperature studied out at 20, 25, 30,35 , and $40{ }^{\circ} \mathrm{C}$, stored at 30 days. The maximum cfu count of bio-formulation (43) was obtained at $25^{\circ} \mathrm{C}$ while it decreased from 30 to $40^{\circ} \mathrm{C}$. (Table- 2). It was obtained that 
the increased temperatures adversely affect the survival of the bio-fertilizers strains. Effect of storage temperature on growth and survival of organism is influenced by both the purity of the culture and the amount of moisture lost during storage (Suryadi et al., 2013). It was reported that cfu count of $R$. japonicum at temperature ranging from 26 to $35^{\circ} \mathrm{C}$ were appreciable, while at a temperature of $40^{\circ} \mathrm{C}$ the mortality rate was high. Similar finding was reported by (Roughley, 1968; Van Schreven, 1970; Saha et al., 2001). Statistical analysis showed that there were significant differences in bio-formulation at different storage temperatures $(\mathrm{p}<0.05)$.

Moisture content is a critical factor for survival of bio-fertilizers strains in bioformulation. The different moisture content was studied out at 20, 25, 30, 35, and $40 \%$, stored at 30 days. The maximum cfu count was obtained at 35 and $40 \%$ moisture. A gradual increased in the cfu count was obtained with increase in moisture content from $20-35 \%$ (Table- 3). The higher moisture level decreases porosity, changes in the structure of carrier particle. The results correlated with the work of (Roughley, 1968). Moisture levels in the range of 30 to 35 per cent were optimal for survival of biofertilizers strains, (Date and Roughley, 1977). An interesting adverse effect of a high moisture level is that numbers of certain strains are highest at 60 to $65 \%$ and reduced carriers to absorb different amounts of moisture may explain the different optima for growth and survival (Roughley, 1968). Statistical analysis showed that the effect of moisture level with cfu was observed significant different $(\mathrm{p}<0.05)$.

\section{Shelf life study}

Bio-fertilizers are usually prepared as carrier based inoculants containing effective microorganisms. The identified strain was used for the preparation of bio-formulation using fly-ash as carrier material and evaluated for their viable cell count during storage period of 180 days. In the present research colony forming units per gram $(\mathrm{cfu} / \mathrm{g})$ of viable count of Enterobacter cloacae HFZ-H4 strain bacterial strain was seen to generally decline during zero days to six months of storage. The maximum population of biofertilizer bacterial strain was found in zero days as compare to other days and was seen up to 180 days. Maximum numbers of colonies were observed (51) (Table 4).

The population of bio-fertilizer bacterial strain was retained at more than $\mathrm{cfu} \mathrm{X} 10^{8} / \mathrm{g}$ in the formulation, through a significant decline in cfu/g was noticed up to 180 days from zero days' storage (Figure 1). (Jayaraj et $a l ., 2005)$, reported that significant decline in cfu/g might be due to decreased viability of propagules and loss of moisture content during passage of time. A decline in population on long time storage may be attributed to the depletion of nutrients, moisture and autolysis of cells (Gaind and Gaur, 2004). There was gradual decrease in the population due to cell shock and the population of Enterobacter cloacae declined up to $6 \log \mathrm{X} 10^{8} \mathrm{cfu} / \mathrm{g}$ after six months of storage which is within the permissible limit (Brahmaprakash and Sahu, 2012). The statistical analysis of data indicates that the shelf life of bio-formulated strain was found to be significant over time $(\mathrm{p}<0.05)$.

\section{References}

Bashan, Y. 1998. Inoculants of plant growth promoting bacteria for use in agriculture. Biotechnology Advances, 16: 729-770.

Brahmaprakash, G. P. and Sahu, P. K. 2012. Bio-fertilizers for Sustainability. Journal of the Indian Institute of Science, 92 1: 37-62.

Cappuccino, J.G. and. Sherman, N. (2004). 
Microbiology: A Laboratory Mannual, Pearson Education, Singapore, $6^{\text {th }}$ edn 119-124.

Chen, Y.P. Rekha, P.D. Arun, A.B. Shen, L.W.A and Young, C.C. 2006. Phosphate solubilising bacteria from subtropical soil and their tricalcium phosphate solubilising abilities. App. Soil Ecol. 34: 33-41.

FCO (Fertilizer Control Order). 2006. The Gazette of India. Extraordinary, PART II Section 3 - Sub-section (ii), published by Authority, New Delhi, Friday, March 24: 5.

Gaind, S. and Gaur, A.C. 2004. Evaluation of Fly-ash as a carrier for diazotrophs and Phosphobacteria, Bio. res. Tech. 95: 187-190.

Gyaneshwar, P. Kumar, G.N. Parkekh, L.J. Poole, P.S. 2002. Role of soil microorganism in improving $\mathrm{P}$ nutrition of plants. Plants Soil 245 83: 51-81.

Illmer, P. Schinner, F. 1995. Solubilising of inorganic calcium phosphates solubilisation mechanisms. Soil Biol. Biochem. 27: 257-263.

Ivanova, R. Bojinova, D. and Nedialkova, K. 2006. Rock phosphate solubilization by soil bacteria, Journal of the University of Chemical Technology and Metallurgy, vol. 41, (3): 297-302.

Jayaraj, J. Radhakrisnan, N.V. Kannan, R. Sakthivel K. Sugnaya D. Venkatesan S and Velazhahan, R. 2005. Development of new formulations of Bacillus subtilis for management of tomato damping off caused by Pythium aphanidermatum, Biocontrol Science and Technology, 15 (I): $55-65$.

Khan, M. S. Zaidi, A. and Wani, P. A. 2007. Role of phosphate-solubilizing microorganisms in sustainable agriculture - A review, Agron. Sustain. Dev., Vol. 27: 29-43.

Khan, M.R. Shahana, M. Fayaz A.M. and Nabilah, K. 2006. Novel process for commercial production of biopesticides, The Webb Law Firm, P. C. Pittsburgh, PA, US.

Kremer, R.J. and Peterson, H.L. 1983. Effects of carrierand temperature on survival of Rhizobium spp. In legume inocula: development of an improved type of inoculant. Applied and Environmental Microbiology, 45: 1790.

Kumar, V.G.; Goswami, G. and Zacharia, K.A. 1999. Flyash: It's Influence on Soil Properties. Indian Society Soil Sci. Workshop, 18-21st October 1999, Calcutta.

Rajakumar, K. and Lakshmanan, M. 1995. Influence of temperature on the survival and nitrogen fixing ability of Azotobacter chroococcum. Indian Journal of Microbiology, 35: 25-30.

Rajankar, P.N., Tambekar, D.H., and Wate, S.R. 2007. Study of phosphate solubilisation efficiencies of Fungi and Bacteria isolated from saline belt of Purna river basin. Research Journal of Agriculture and Biological Sciences. 3 (6): 701-703.

Rao, N.S. 1986. Bio-fertilizers in Agriculture, Oxford and IBH Publishing Co. New Delhi. $4^{\text {th }}$ printing 2-16

Rashid, M. Samina, K. Najma, A. Sadia, A. and Farooq, L. 2004. Organic acids production and phosphate solubilization by phosphate solubilizing microorganisms under in vitro conditions, Pak. J. Biol. Sci., vol. 7: 187-196.

Rodríguez, H. and Fraga R. 2007. Phosphate solubilizing bacteria and their role in plant growth promotion in Arabidopsis thaliana. Vol. 20. No. 2: 207-217.

Roughly, R. J. 1968. Some factors influencing the growth and survival of root nodule bacteria in peat culture. J. Appl. Bacteriol., 31: 259-265.

Saha, A. K., Deshpande, M. V. and Kapadnis, B. P. 2001. Studies on survival of 
Rhizobium in the carriers at different temperature using green fluorescent protein marker. Curr. Sci., 80, 5: 69671.

Saleh, E. A., Nassar, F. R. and Yassen, A. M. 2001. Survival of microorganisms of multi-strains inoculant on different carriers. Annals of Agricultural Science, 39: 2163-2169.

Singh, S. and Kapoor, K.K. 1994. Solubilization of insoluble phosphates by bacteria isolated from different sources, Environ Ecol, vol. 12: 51-55.

Suryadi, Y. Dwi, N.S. Zaffan, N. Hikmawati and Mubarik, N. R. 2013. Bioformulation of antagonistic bacterial consortium for controlling blast, sheath blight and bacterial blight diseases on rice. Asian Journal of Plant Pathology. 7: 92-108.

Thungtrakul, M. 1987. Factors affecting survival of rhizobia in carriers. Thesis. Kasetsart University, Thailand.

Van Schreven, D. A. 1970. Some factors influencing growth and survival of Rhizosphere spp. in soul peat cultures. Plant Soil, 32: 113-130.

Vitekari, H.N, Talele, A.P. Mane, R.G. Gaikwad, V.S. and Shah, J.V. 2012. Fly ash based biopesticides: a comprehensive review. International Journal of Pharmacy and Biological Sciences 2 (1): 76-82.

\section{How to cite this article:}

Mohammad Hafeez, P.W. Ramteke, Rubina Lawrence, Rambharose, B.G. Suresh, Supriya Kumari, Ajay Kumar Singh, Ankit Singla, Anupriya Paul, Shalini Masih and Harison Masih. 2018. Bio-formulation of Halotolerant Phosphate Solubilizing Enterobacter cloacae Strain to Screen Different Carrier Materials and their Shelf Life Study. Int.J.Curr.Microbiol.App.Sci. 7(01): 2373-2380. doi: https://doi.org/10.20546/ijcmas.2018.701.285 